\title{
Geochronology and REE geochemistry of zircon and garnet in pelitic gneisses from the Higo metamorphic terrane, Kyushu, Japan: Constraints on the timing of high-temperature metamorphism
}

\author{
Vuong BuI THI SinH ${ }^{*}$, Yasuhito OSANAI ${ }^{* *}$, Nobuhiko NAKANO ${ }^{* *}$, Tatsuro AdACHI ${ }^{* *}$ and Ippei Kitano** \\ * Graduate School of Integrated Sciences for Global Society, Kyushu University, Fukuoka 819-0395, Japan \\ ** Division of Earth Sciences, Faculty of Social and Cultural Studies, Kyushu University, Fukuoka 819-0395, Japan
}

\begin{abstract}
The Higo metamorphic terrane in west-central Kyushu, southwest Japan, consists of a sequence of greenschistto granulite-facies metamorphic rocks. This study reports the U-Pb Zrn ages and rare earth elements (REE) characteristics of Zrns and Grts from pelitic gneisses in the Higo metamorphic terrane to constrain its timing of high-temperature metamorphism. Based on the morphology, internal textures, occurrences, Th/U ratios, REE patterns and ages of Zrn, and the heavy REE (HREE) partition coefficient between Zrn and Grt, the results indicate that the prograde metamorphism occurred at $\sim 120 \mathrm{Ma}$ immediately after precursor deposition at 120 $130 \mathrm{Ma}$ and peak metamorphic conditions were attained during the period between 110 and $120 \mathrm{Ma}$. The $\sim 110$ Ma age might be indicative of the onset of cooling and exhumation after the peak metamorphic stage. Retrograde metamorphism continued at least to $105 \mathrm{Ma}$ as obtained from Zrns in the granitic intrusion.
\end{abstract}

Keywords: Higo metamorphic terrane, U-Pb ages, Zircon, Garnet, Rare earth elements

\section{INTRODUCTION}

In recent geological and petrological investigations throughout the world, $\mathrm{Zrn} \mathrm{U}-\mathrm{Pb}$ chronology has been the most convincing age determination method for highand ultrahigh-temperature (HT-UHT) metamorphic rocks. Because of the durability of Zrns against chemical and physical processes, it can record the ages of several geological events such as magmatism and metamorphism. Generally, to interpret Zrn ages, Zrn crystal morphology, internal zonal structures and $\mathrm{Th} / \mathrm{U}$ ratios have been applied (e.g., Hoskin and Schaltegger, 2003; Wu and Zheng, 2004). Zrns with the euhedral shape, well-developed growth zoning (e.g., oscillatory), and the high- $\mathrm{Th} / \mathrm{U}$ ratio $(>0.10)$ are normally recognized as those of magmatic origin, while those of metamorphic origin are characterized by a rounded or ovoid shape showing a structureless internal texture, sector or fir-tree zoning, and the low- $\mathrm{Th} / \mathrm{U}$ ratio $(<0.10)$ (e.g., Hoskin and Schaltegger, 2003). How-

doi:10.2465/jmps.181115

T.S.V. Bui, 3GS17013Y@s.kyushu-u.ac.jp Corresponding author Y. Osanai, osanai@ scs.kyushu-u.ac.jp ever, these criteria are not always supported, particularly in the case of metamorphic Zrn in HT metamorphic rocks because the growth or replacement of the $\mathrm{Zrn}$ can occur during several stages of HT metamorphism including crystallization from melts during crustal anataxis (e.g., Rubatto, 2002), solid-state mineral reactions via metamorphic breakdown reactions (e.g., Fraser et al., 1997), and recrystallization of protolith Zrns (e.g., Hoskin and Black, 2000). Thus, to understand the meaning of $\mathrm{Zrn}$ ages, it is necessary to consider the behaviors of metamorphic Zrn during HT metamorphism. Recently, Zrn trace element geochemistry has been utilized to investigate the processes or conditions of $\mathrm{Zrn}$ growth/recrystallization (e.g., Whitehouse and Platt, 2003; Hokada and Harley, 2004; Rubatto, 2017). In addition, REE partitioning between $\mathrm{Zrn}$ and Grt $\left(\mathrm{D}_{\mathrm{Zrn} / \mathrm{Grt}}\right)$ has been applied to connect $\mathrm{Zrn}$ age with metamorphic condition through the assessment of their equilibrium (e.g., Harley, 2002; Rubatto, 2002; Whitehouse and Platt, 2003). Both Zrn and Grt prefer HREE relative over light to middle REE (L-MREE), resulting in equilibrium ${ }^{\mathrm{HREE}} \mathrm{D}_{\mathrm{Zrn} / \mathrm{Grt}}$ values that are near unity (Harley, 2002; Whitehouse and Platt, 2003). There- 
fore, the combination of external, internal, and geochemical characteristics as well as Zrn behavior during HT metamorphism is crucial to link $\mathrm{Zrn} \mathrm{U-Pb}$ ages to the geological events.

The Higo metamorphic terrane has been recognized as one of the HT metamorphic terranes in Japan. It consists of high-grade metamorphic rocks up to UHT granulite-facies that are characterized by a clockwise $P-T$ evolution and peak metamorphic conditions of 7.8-9.0 kbar and $900-960{ }^{\circ} \mathrm{C}$ (Osanai et al., 1998). Previously, this terrane was proposed to have metamorphosed at $\sim 260-230$ Ma (Osanai et al., 1998; Hamamoto et al., 1999; Osanai et al., 2006); however, the recently conducted Zrn geochronology has suggested that the timing of HT-UHT metamorphism is approximately 110-120 Ma because of clustered age data (Sakashima et al., 2003; Takagi and Arai, 2003; Dunkley et al., 2008; Maki et al., 2014; Osanai et al., 2017; Suga et al., 2017). Though its metamorphic evolution in terms of petrography has been well understood, of which the prograde and retrograde metamorphic processes for each metamorphic zone were well reported on the basis of reaction textures, chemical zoning of minerals, and mineral inclusions in porphyroblasts (Hamamoto et al., 1999; Maki et al., 2004; Osanai et al., 2006), it is still obscured in term of $P-T-t$ evolution because of the lack of information regarding the timing of the prograde and retrograde stages. To solve this problem, investigations of geochemical features and the behavior of metamorphic Zrn related to Grt can be useful. Thus, in this study, we applied laser ablation inductively couple plasma mass spectroscopy (LA-ICP-MS) U-Pb isotopic dating to Zrns as well as REE analyses of Zrns and Grts from pelitic gneisses in the Higo metamorphic terrane. Showing the behaviors of the Zrn and Grt, this study constraints the timing of HT metamorphism. Minerals abbreviation used in this paper is that of Whitney and Evans (2010).

\section{GEOLOGICAL SETTING AND SAMPLE DESCRIPTION}

The Higo metamorphic terrane is in the central-western part of Kyushu and is a sequence of metamorphic rocks with increasing metamorphic grade southward from greenschist- to granulite-facies (Obata et al., 1994; Osanai et al., 1998) (Fig. 1). The five metamorphic zones are defined by metapelite mineral assemblages as follows: zone $\mathrm{A}$ by $\mathrm{Chl}+\mathrm{Ms}$, zone $\mathrm{B}$ by $\mathrm{Bt}+\mathrm{Ms}+\mathrm{And}$, zone $\mathrm{C}$ by $\mathrm{Kfs}+\mathrm{Sil}+\mathrm{Bt}$, zone D by $\mathrm{Grt}+\mathrm{Crd}+\mathrm{Bt}$, zone $\mathrm{E}$ by Opx-bearing granulite (Obata et al., 1994), and zone F by hyper aluminous Spr-bearing granulite only found in association with the meta-peridotite intrusion in zone $\mathrm{C}$ (Osanai et al., 2006) (Fig. 1). The metamorphism was

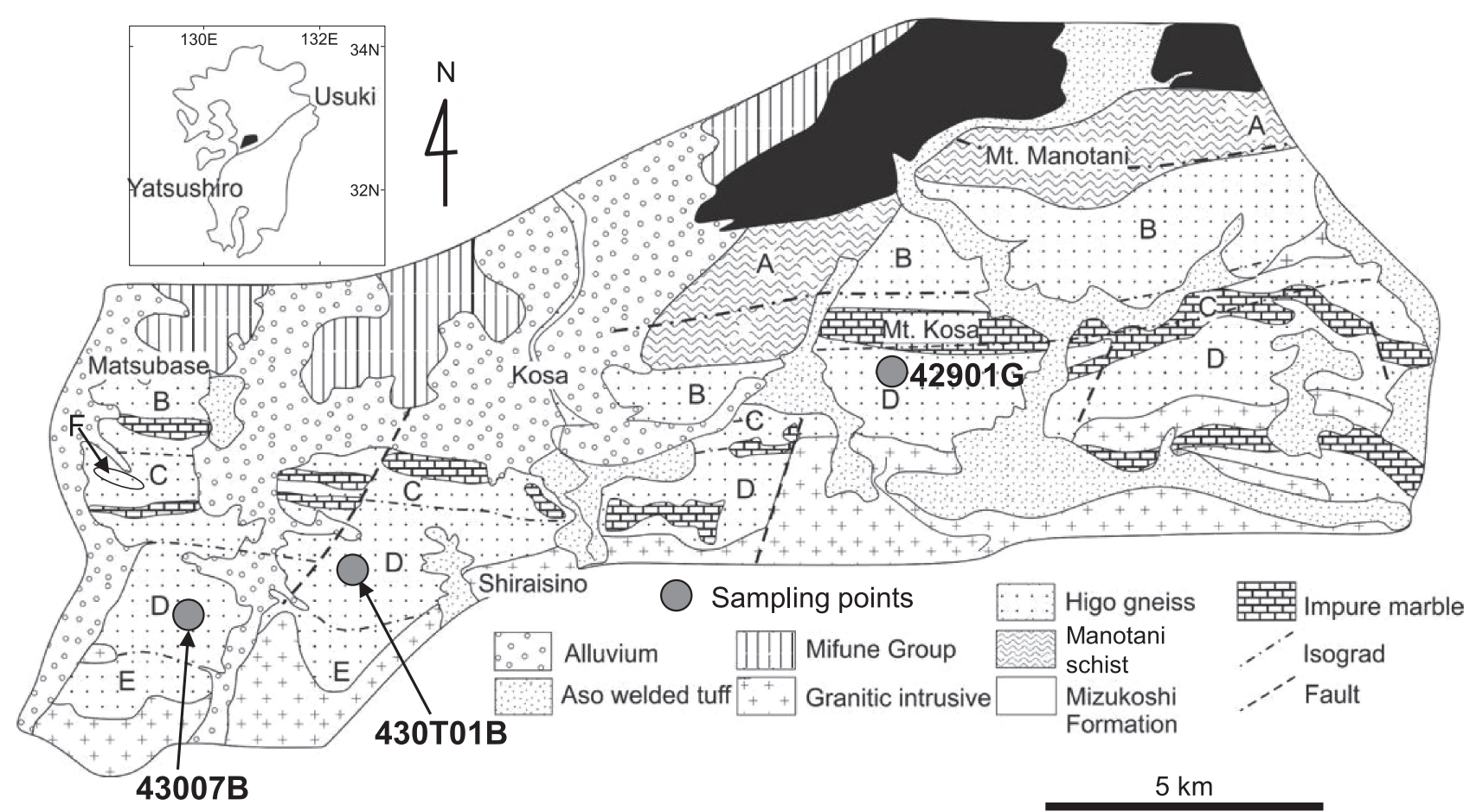

Figure 1. Metamorphic zonation of the Higo metamorphic terrane defined by the mineral assemblages of the metapelites (Obata et al., 1994; Osanai et al., 2006). Zone A by Chl + Ms, zone B by Bt $+\mathrm{Ms}+\mathrm{And}$, zone C by Kfs $+\mathrm{Sil}+\mathrm{Bt}$, zone $\mathrm{D}$ by Grt $+\mathrm{Crd}+\mathrm{Bt}$, zone $\mathrm{E}$ by Opxbearing granulite, and zone $\mathrm{F}$ by Spr-bearing granulite. The gray points indicate the sample localities in this study. 
also recorded for each zone corresponding to their mineral assemblage as follows: greenschist-facies in zone A, amphibolite-facies in zones B and C, and granulite-facies in zones D and E (Obata et al., 1994; Osanai et al., 1998). In addition, the $P-T$ conditions have been estimated for each zone as follows: $3.5-4.2 \mathrm{kbar}$ and $640-720{ }^{\circ} \mathrm{C}$ for zone C, 4.8-6.0 kbar and $740-820^{\circ} \mathrm{C}$ for zone $\mathrm{D}, 6.0-7.2$ kbar and $800-870{ }^{\circ} \mathrm{C}$ for zone $\mathrm{E}$, and 7.8-9.0 kbar and 900-960 ${ }^{\circ} \mathrm{C}$ for zone $\mathrm{F}$ (Osanai et al., 1998).

In this study, we analyzed Grt-Crd-Bt gneiss (43007B), Grt-Bt gneiss (430T01B), and discordant Bt granite (42901G) collected from zone D (Fig. 1). These gneisses show the migmatitic textures (Fig. 2a) and were intruded by later discordant granite (Fig. 2b). The GrtCrd-Bt gneiss consists of Grt, Crd, Bt, Pl, Kfs, and Qz (Fig. 2c) with accessory fibrolite, Ap, Zrn, Mnz, and Gr. Fibrolite only occurs as an inclusion in Crd and Grt (Figs. $2 \mathrm{~d}$ and 2e). Porphyroblastic Grt contains numerous finegrained inclusions of fibrolite that occur only in the rim (Fig. 2e), Bt, Qz, Pl, Ap, Zrn, and Mnz. The Grt resorption texture is observed, which is surrounded by the secondary Bt and/or Crd, Qz, and Pl (Fig. 2c). Crd also occurs as a subhedral porphyroblast with inclusions such as $\mathrm{Bt}$ and fibrolite (Fig. 2d). The Grt-Bt gneiss also shares quite similar petrographical features to those of Grt-CrdBt gneiss, without the presence of fibrolite and Crd (Figs. $2 \mathrm{f}$ and $2 \mathrm{~g}$ ). The Grt porphyroblasts in this gneiss are partly surrounded by Bt and Pl (Fig. 2f) or maintain a preserved euhedral shape (Fig. 2g). In addition, some Pl shows the subhedral to euhedral shape (Figs. $2 \mathrm{f}$ and $2 \mathrm{~g}$ ). Zrn occurs as inclusions in Grt (only in the Grt-Bt gneiss: Fig. 2g), Bt, Qz, and Pl with/without $\mathrm{Crd}$ and in the matrix, particularly near the Grt resorption area (Fig. 2c). The discordant Bt granite contains abundant coarsegrained Qz and Pl (Fig. 2h) along with subordinate amounts of $\mathrm{Bt}$ and minor accessory minerals including Ap, Zrn, and Mnz. Secondary Prh is occasionally found with Bt (Fig. 2h). Zrn crystals in this rock are notably quite euhedral, occurring in the matrix or included in the $\mathrm{Pl}, \mathrm{Qz}$, and $\mathrm{Bt}$.

\section{U-Pb ZRN DATING AND REE CHARACTERISTICS}

$\mathrm{U}-\mathrm{Pb}$ dating for $\mathrm{Zrn}$ separated from pelitic gneisses and discordant granite and REE analyses for the separated $\mathrm{Zrn}$ and Grt in thin section (for the pelitic gneisses) were performed using an Agilent 7500cx quadrupole ICP-MS with a New Wave Research UP-213 Nd-YAG UV (213 $\mathrm{nm}$ ) laser ablation system at Kyushu University, Japan. These analytical procedures are described in detail by Adachi et al. (2012) for the dating and Nakano et al.
(2010) for the REE analyses. The error of all analyses is 2 sigma intervals. The analytical results for the age and REE composition of the Zrn grains are listed in Supplementary Tables S1 and S2, respectively; major element and REE compositions of the Grt are presented in Supplementary Tables S3 and S4, respectively (Supplementary Tables S1-S4 are available online from https:// doi.org/10.2465/jmps.181115).

Grt-Crd-Bt gneiss (43007B) contains transparent to translucent Zrns with ovoid, stubby, and minor elongated shapes, 40-100 $\mu \mathrm{m}$ in length. The cathodoluminescence (CL) images of these Zrns exhibit a faintly oscillatory to unzoned dark-CL core overgrown by a bright-CL structureless rim or sector zoned or structureless grains without any rim (Figs. 3a and 3b). The core and sector zoned grains mostly show high- Th/U ratios $(>0.10)$ and scattered ages of $\sim 150-280,350,450-500,650,900,1000$, 1650, and $1850 \mathrm{Ma}$ (Figs. 3a, 3b, and 3h). However, five data points from the structureless overgrown rims and grains provide clustered data with a weighted mean age of $114.4 \pm 2.4 \mathrm{Ma}(n=5, \mathrm{MSWD}=0.51)$ and low-Th/U ratios $(<0.10)$ (Figs. $3 b$ and $3 g$ ).

In the Grt-Bt gneiss (430T01B), the Zrn grains are 80-200 $\mu \mathrm{m}$ in length, have long prismatic subhedral to euhedral with a lesser amount of ovoid to equant shapes, colorless, and transparent. Their internal texture shows banded oscillatory zoning, blurred zoning, and core-rim textures with an oscillatory zoned core overgrown or truncated by the unzoned or faintly oscillatory zoned rim (Figs. 3c and 3d). The blurred zoning grain and the truncating rim show $\mathrm{Th} / \mathrm{U}$ ratios of approximately 0.10 and an age range of 121-125 Ma, which defines a weighted mean age of $123.2 \pm 2.5 \mathrm{Ma}(n=4, \mathrm{MSWD}=0.65)$ (Figs. 3d and $3 \mathrm{~g}$ ). The unzoned or faintly oscillatory rims overgrowing the core show low- $\mathrm{Th} / \mathrm{U}$ ratios $(<0.10)$ and concordant data of 105-115 Ma (concordia age of 111.2 \pm $2.0 \mathrm{Ma} ; n=7$, MSWD = 0.14) (Figs. 3d and 3g). Similar ages of $107-118 \mathrm{Ma}(111.0 \pm 1.1 \mathrm{Ma}, n=29, \mathrm{MSWD}=$ $0.92)$ were also obtained from sub- to euhedral grains with banded oscillatory zoning and scattered $\mathrm{Th} / \mathrm{U}$ ratios of $0.06-1.21$ (Figs. 3d and 3g). The relic core indicates an age population of $\sim 130-180,210-300,350-400,800$, 1800, and $2100 \mathrm{Ma}$ with high-Th/U ratios (Figs. 3c, 3d, and $3 \mathrm{~h})$.

Discordant Bt granite (42901G) contains transparent to translucent Zrns with sub- to euhedral or ovoid shapes, 30-70 $\mu \mathrm{m}$ in length. The CL images of these Zrns show mainly structureless zoning and a small number of faintly oscillatory zoning or core-rim textures with an unzoned core overgrown by a structureless thin rim (Figs. 3e and 3f). The core and weak oscillatory zoned grains show high-Th/U ratios $(>0.10)$ and scattered ages of $\sim 150$ 

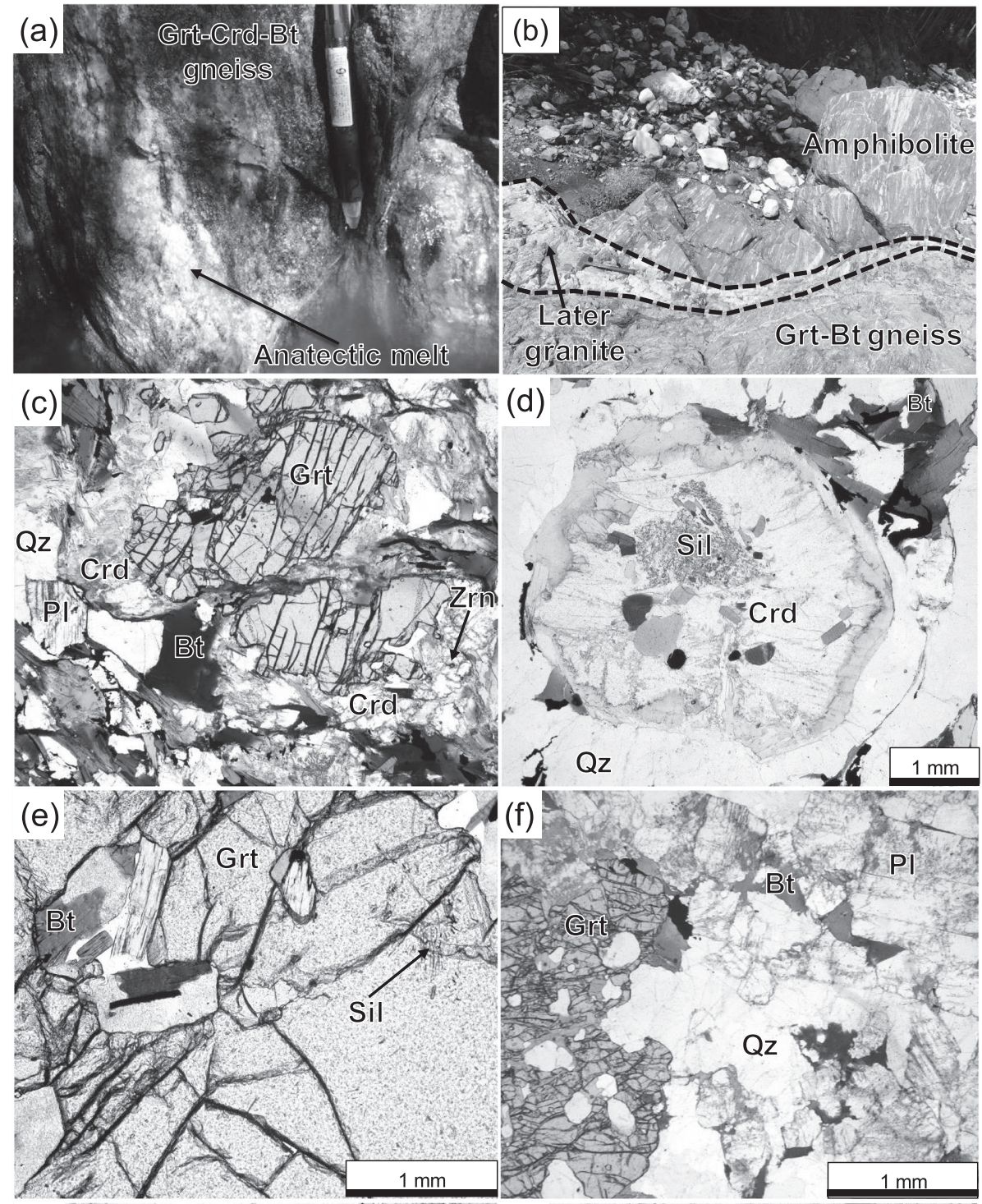

Figure 2. Mode of occurrence (a) and (b). Photomicrographs of the Grt-Crd-Bt gneiss (c), (d), and (e). Grt-Bt gneiss (f) and (g). Bt granite (h). (a) Migmatitic texture with anatectic melt observed in the Grt-Crd-Bt gneiss. (b) Grt-Bt gneiss and amphibolite intruded by later granite. (c) Grt porphyroblast partly replaced by $\mathrm{Crd}, \mathrm{Bt}$, and Qz in the Grt-Crd-Bt gneiss. (d) Subhedral Crd porphyroblast occurring with inclusions of Sil and $\mathrm{Bt}$ and pinitized rim in the Grt-Crd-Bt gneiss. (e) Sil occurs as fibrolite in the Grt rim in the Grt-Crd-Bt gneiss. (f) Grt porphyroblast partly replaced by $\mathrm{Bt}$, $\mathrm{Qz}$, and $\mathrm{Pl}$ in the Grt-Bt gneiss; the euhedral shape of $\mathrm{Pl}$ is also apparent. (g) Euhedral Grt porphyroblast including euhedral $\mathrm{Pl}$ and Zrn inclusions in the Grt-Bt gneiss. (h) Coarse-grained $\mathrm{Qz}$ and $\mathrm{Pl}$ as well as Prh lenses in the discordant $\mathrm{Bt}$ granite. Color version is available online from https://doi.org/10. 2465/jmps. 181115 .

210, 280, 330, 750, and $1700 \mathrm{Ma}$ (Figs. 3e and 3f). However, seven data points from structureless grains provide clustered data (concordant age $=105.6 \pm 1.3 \mathrm{Ma}, n=7$, $\mathrm{MSWD}=1.8)$ with low-Th/U ratios $(<0.10)$ (Fig. 3f).

The REE patterns normalized to chondrite values
(McDonough and Sun, 1995) of some representative analyzed Zrns in both pelitic gneisses were characterized by steep patterns enriched in HREE relative to LREE with a negative $\mathrm{Eu}$ anomaly and a weak positive Ce anomaly (Fig. 4). However, in the Grt-Bt gneiss, the $\sim 120 \mathrm{Ma}$ 

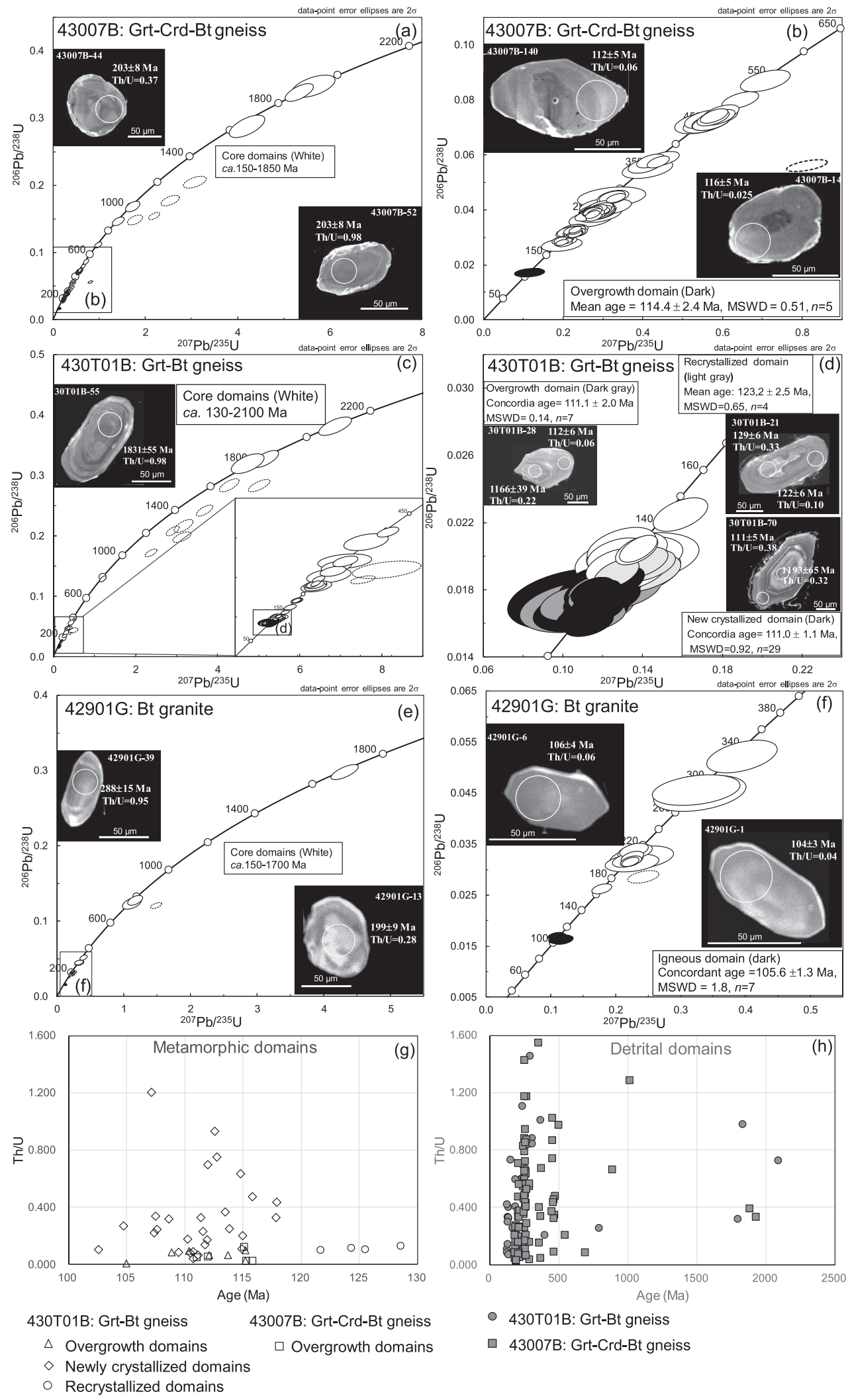

- 430T01B: Grt-Bt gneiss

प 43007B: Grt-Crd-Bt gneiss

Figure 3. Concordia diagrams for the results of LA-ICP-MS Zrn U-Pb dating and the representative CL images of the analyzed Zrns with the analytical spots, ${ }^{206} \mathrm{~Pb} /{ }^{238} \mathrm{U}$ ages, and $\mathrm{Th} / \mathrm{U}$ ratios shown for the Grt-Crd-Bt gneiss (a) and (b). Grt-Bt gneiss (c) and (d). Bt granite (e) and (f). In the concordia diagrams, concordant and discordant data are shown with solid and dash ellipses, respectively. Th/U ratio-age plots are shown for the metamorphic domains (g) and detrital domains (h). 

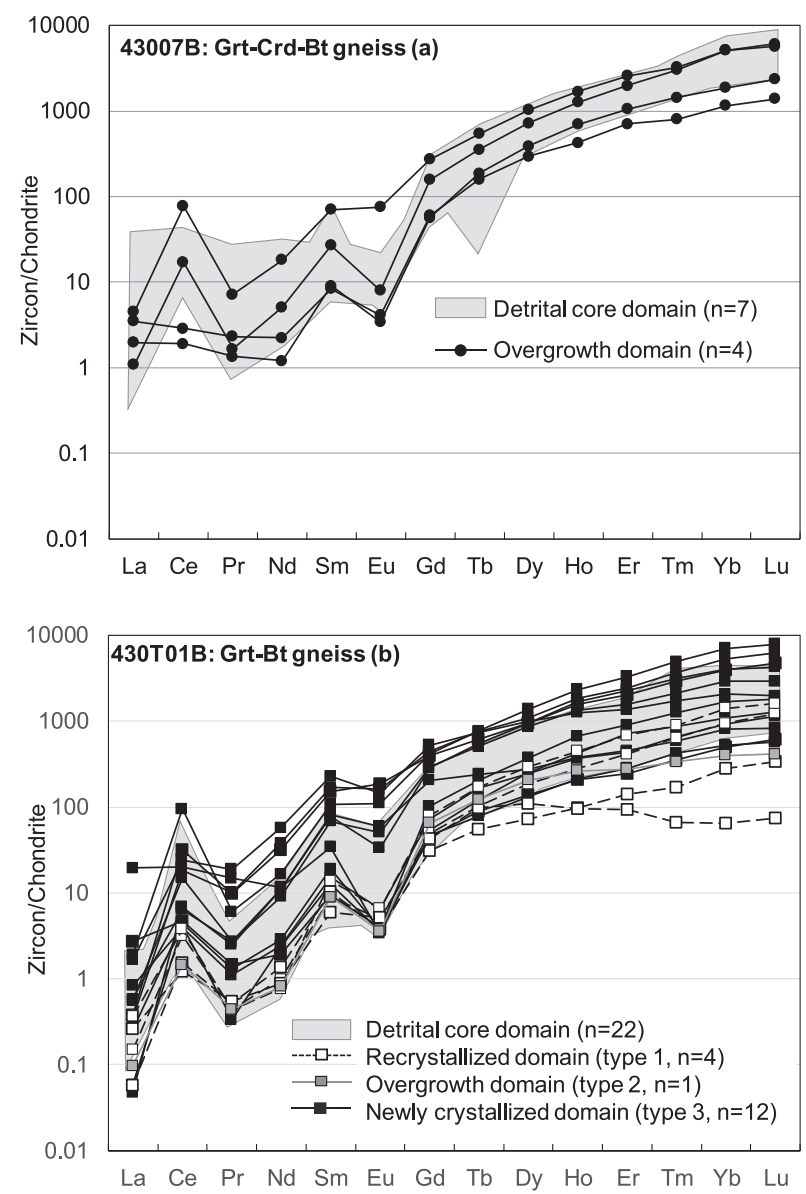

Figure 4. REE patterns normalized by chondrite value for the $\mathrm{Zrn}$ from the Grt-Bt gneiss (a). Grt-Crd-Bt gneiss (b). The gray shadow indicates the inherited core domain, the dashed black line the $\sim 120$ Ma domain, solid black line for the newly crystallized domain $(\sim 110 \mathrm{Ma})$, and gray line for the overgrowth domain $(\sim 110 \mathrm{Ma})$. See the text for the details. Chondrite values are after McDonough and Sun (1995).

and other older Zrns show mostly similar REE concentrations and patterns, while most of the $\sim 110 \mathrm{Ma} Z \mathrm{rn}$ grains are relatively enriched in LREE compared to the others (Fig. 4b).

\section{MAJOR ELEMENTS AND REE COMPOSITION OF GRT}

Prior to Grt analysis, X-ray elemental maps were developed for major elements (Fe, Mn, $\mathrm{Mg}$, and $\mathrm{Ca}$ ) and $\mathrm{Y}$ for both pelitic gneisses. Grt in the Grt-Crd-Bt gneiss (43007B) has relatively wide homogeneous core zones which have a lower $\mathrm{Mn}$ and higher $\mathrm{Mg}$ core than that of the thin rim (Fig. 5a). $\mathrm{X}_{\mathrm{Mg}}\left[\mathrm{Mg} /\left(\mathrm{Mg}+\mathrm{Fe}^{2+}\right)\right]$ values increase from the core $\left(\mathrm{X}_{\mathrm{Mg}}=0.24\right)$, reaching a maximum value in the mantle $\left(\mathrm{X}_{\mathrm{Mg}}=0.25\right)$ and decreasing again to the rim $\left(\mathrm{X}_{\mathrm{Mg}}=0.22-0.23\right)$ (Table $\left.\mathrm{S} 3\right)$. Ca is near- ly constant throughout the grain with $\mathrm{Ca}$ (pfu) ranging from 0.17 to 0.18 (Table S3). In contrast, the Grt in the Grt-Bt gneiss (430T01B) shows normal chemical zoning with an increase in $\mathrm{Mg}$ and $\mathrm{Ca}$, a decrease in $\mathrm{Mn}$ toward the rim and a subsequent decrease in $\mathrm{Mg}$ and $\mathrm{Ca}$, and an increase in $\mathrm{Mn}$ at the outer rim (Fig. 5b). $\mathrm{X}_{\mathrm{Mg}}$ values gradually increase from the core $\left(\mathrm{X}_{\mathrm{Mg}}=0.20\right)$ to the $\operatorname{rim}\left(\mathrm{X}_{\mathrm{Mg}}=0.28\right)$ (Table S3). The Grt for both samples is rich in almandine and poor in grossular (Xalm $=0.65-$ 0.72; Xgrs $=0.03-0.07$, Figs. 5c and 5d). However, the yttrium zoning patterns of Grt in both gneisses are similar and gradually decreases from the core toward the rim (Figs. 5a and 5b). HREE zoning of Grt is considered to be correlated with mapped Y zoning defining the coremantle-rim texture. All of the Grt core shows the highest $\mathrm{Y}$ concentration, decreasing toward the mantle and rim. The REE patterns of the Grt from both samples are similar with following features: strong LREE depletion, a negative Eu anomaly, and an MREE to HREE with a positive slope for the Grt core, a slightly positive to flat slope for the Grt mantle, and a flat to slightly negative slope for the Grt rim (Figs. 6a and 6b).

\section{DISCUSSION}

\section{Metamorphism characteristics for collected pelitic gneisses and retrogression features}

Both pelitic gneisses were collected from zone D (Fig. 1) with the similar $\mathrm{X}_{\mathrm{Mg}}$ values of Grt (Figs. 5c and 5d) possibly indicating that these samples were subjected to a similar metamorphic temperature condition. Therefore, the absence of Crd in the Grt-Bt gneiss while present only in the Grt-Crd-Bt gneiss could be a result of the difference in bulk chemistry. Petrographically, the Grt-Crd-Bt gneiss is mainly composed of Grt, $\mathrm{Crd}, \mathrm{Bt}, \mathrm{Pl}, \mathrm{Kfs}$, and Qz. Some Grts show resorption texture, of which Grts are partly replaced by $\mathrm{Bt}$ or $\mathrm{Crd}$ suggesting a retrograde reaction: $\mathrm{Grt}+\mathrm{Kfs}+$ melt $\rightarrow \mathrm{Bt}+\mathrm{Crd}+\mathrm{Qz}$ (Maki et al., 2004; Miyazaki, 2004). The Sil occurrence as fibrolite inclusions in the Grt and Crd porphyroblasts may indicate a melting reaction at a temperature for $\mathrm{Qz}+\mathrm{Kfs}+\mathrm{Pl}$ bearing assemblages as follows: $\mathrm{Bt}+\mathrm{Sil}+\mathrm{Qz} \rightarrow \mathrm{Kfs}+\mathrm{Crd}+$ Grt + melt (Maki et al., 2004; Miyazaki, 2004). The Grt$\mathrm{Bt}$ gneiss also contains a similar mineral assemblage excluding Crd and Sil. Some Grt shows resorption texture, replaced by $\mathrm{Bt}, \mathrm{Pl}$, and $\mathrm{Qz}$, suggesting a hydration retrograde reaction. These petrographical characteristics for the Grt-Crd-Bt gneiss are typical for those reported from zone D (Obata et al., 1994, Maki et al., 2004) which underwent peak $P-T$ condition of 4.8-6.0 kbar and 740-820 ${ }^{\circ} \mathrm{C}$ (Osanai et al., 1998). 

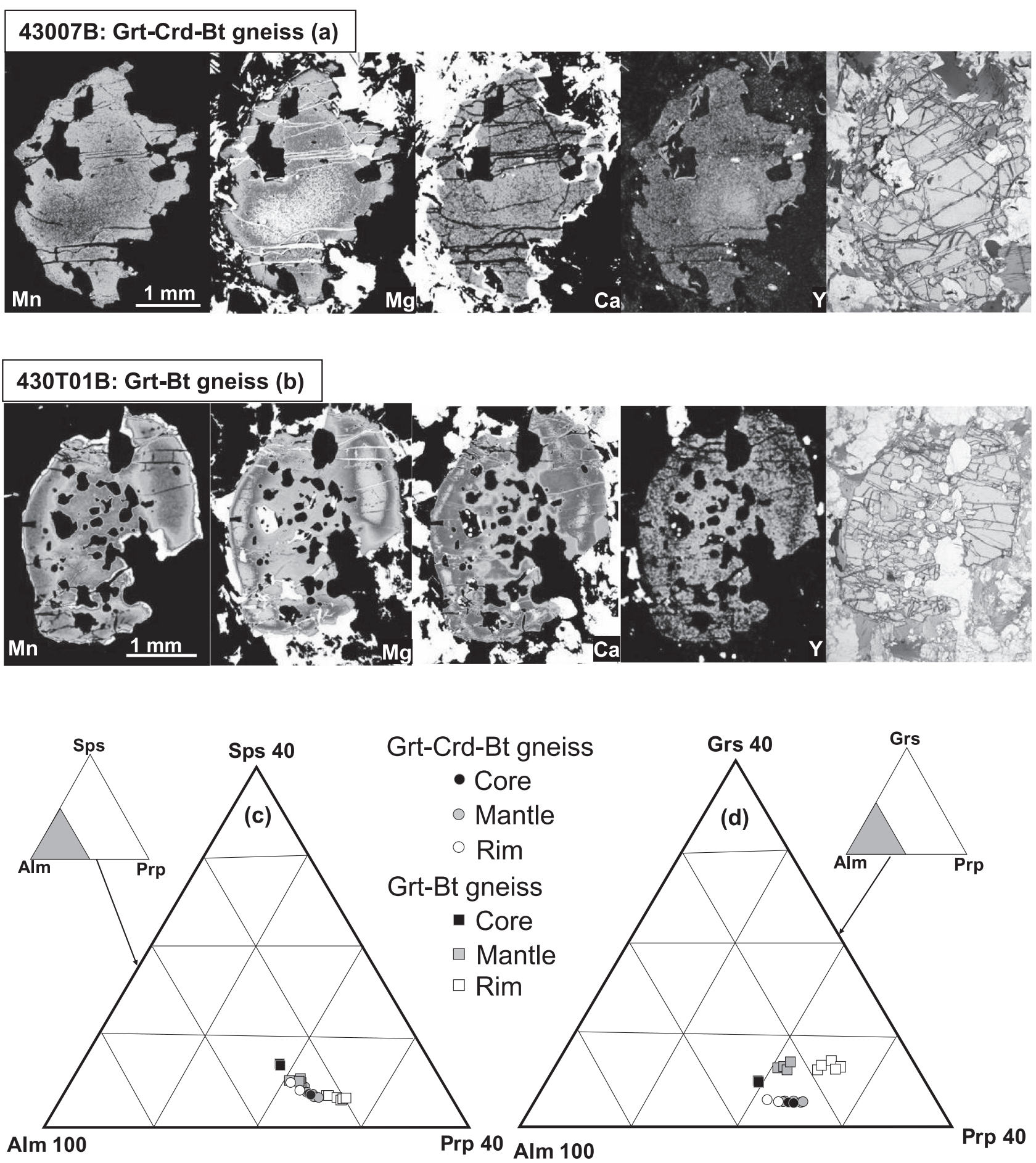

Figure 5. $\mathrm{X}$-ray images for $\mathrm{Mn}, \mathrm{Mg}, \mathrm{Ca}$ and $\mathrm{Y}$ in the Grt of the Grt-Crd-Bt gneiss (a), the Grt-Bt gneiss (b). Their chemical composition is shown in (c) and (d). Color version is available online from https://doi.org/10.2465/jmps.181115.

The pelitic gneisses analyzed in this study were highly retrogressed/re-hydrated during fluid infiltration affecting the discordant granite. Given the distribution and textural-chemical features of the late-forming $\mathrm{Bt}$, Crd, and Prh, at least two stages of re-hydration are recorded. The first stage of re-hydration is evidenced by extensive secondary Bt and/or Crd after Grt porphyroblasts (Figs. 2c and 2f). A second stage of subsequent re-hydration appears to have occurred under relatively lower $\mathrm{T}$ conditions, as inferred from the abundant secondary Prh occurring as veins or lenses in the cleavages of the $\mathrm{Bt}$ in the discordant Bt granite (Fig. 2h), which could 


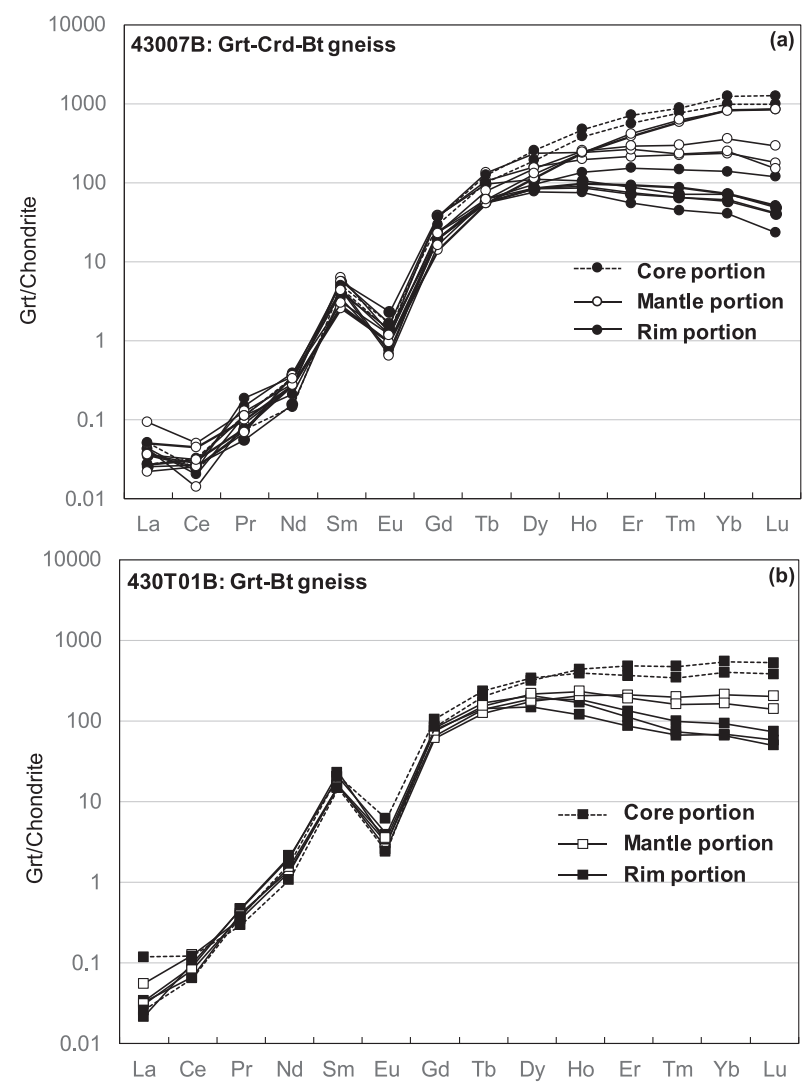

Figure 6. REE pattern normalized by chondrite value for Grt from the Grt-Crd-Bt gneiss (a). Grt-Bt gneiss (b). See the text for the details. Chondrite values are after McDonough and Sun (1995).

have formed because of the retrograde effects of the host gneisses after granite crystallization had completed.

\section{Interpretation of $\mathrm{Zrn} \mathrm{U}-\mathrm{Pb}$ ages}

The discordant Bt granite contains sub- to euhedral or ovoid Zrns with the internal texture of structureless to core-rim structures or faintly oscillatory zone. The relic core and weak oscillatory domains obtained the scattered data between $\sim 150$ and 1700 Ma with relatively high$\mathrm{Th} / \mathrm{U}$ ratios $(>0.1)$ (Figs. 3e and 3f). However, the clustered ages of $\sim 105 \mathrm{Ma}$ was calculated from the other unzoned euhedral Zrn grains which completely isolated from the old ones; therefore, it is constrained as timing of emplacement/crystallization of this discordant granite. The older data are similar to the detrital ages obtained from the pelitic gneisses (Figs. 3a, 3c, and 3e) which may propose that this $\mathrm{Bt}$ granite might be formed by the partial melting of the pelitic gneisses. However, it is still obscured and further study for bulk chemistry is required to tackle this problem.

Analyzed Zrns in the pelitic gneisses are mainly characterized by rounded termination morphology with a sub- to euhedral or ovoid shape and internal features of core-rim zonation. The Zrn relic cores show obvious to faint oscillatory or sector zoning and scattered dates between $\sim 130$ and $2100 \mathrm{Ma}$ with relatively high-Th/U ratios (mostly higher than 0.10) (Figs. 3a, 3c, and 3g). These results strongly indicate that these zoned $\mathrm{Zrn}$ cores preserve inherited detrital domains of magmatic origin. The youngest detrital Zrn cores shows a maximum depositional age pooled at $\sim 130 \mathrm{Ma}$, approximately $50 \mathrm{Ma}$ younger than previously reported by Suga et al. (2017). In contrast, the rim domains, which truncate or overgrow the relic cores, and the domains with a variety of internal zoning such as banded oscillatory and blurred zoning and unzoned to faint oscillatory zoning show concentrated ages of $\sim 110$ and $120 \mathrm{Ma}$, with $\mathrm{Th} / \mathrm{U}$ ratios of $0.06^{-}$ 1.21 (Figs. 3b, 3d, and 3g). These distinct ages from detrital Zrns might indicate metamorphism timing, which is quite consistent with previous reports (Sakashima et al., 2003; Takagi and Arai, 2003; Dunkley et al., 2008; Maki et al., 2014; Osanai et al., 2017; Suga et al., 2017).

\section{Zrn growth in relation to Grt: Constraining the high- temperature metamorphism timing}

Based on internal texture and morphology, three metamorphic Zrn types can be categorized as follows: type 1: recrystallization (replacement), type 2: overgrowth, and type 3: newly crystallized Zrn following the definition of Rubatto (2017). Type 1 is characterized by an unzoned or faintly oscillatory zoned rim that truncates the inherited core (Figs. 7a and $7 \mathrm{~b}$ ) and blurred zoning (Figs. $7 \mathrm{c}$ and $7 \mathrm{~d}$ ) with the $\mathrm{Th} / \mathrm{U}$ ratios of $\sim 0.10$ (Fig. 3g); its mean age is $\sim 120 \mathrm{Ma}$ (Fig. 3d). Type 2 is an ovoid metamorphic Zrn composed of an oscillatory zoned or homogenous core and a faint oscillatory zoned to unzoned rim (Figs. 7e and 7f) with low-Th/U ratios $(<0.10)$ (Fig. $3 g$ ). Type 3 is sub- to euhedral Zrn with the oscillatory zoning (Figs. $7 \mathrm{~g}$ and $7 \mathrm{~h}$ ) and more scattered $\mathrm{Th} / \mathrm{U}$ ratios of $0.06-1.21$ (Fig. $3 \mathrm{~g}$ ), similar to magmatic $\mathrm{Zrn}$. The last two types of $\mathrm{Zrn}$ have a similar concordia age of $\sim 110 \mathrm{Ma}$. The REE chemistries of the three types of metamorphic Zrns exhibit similar REE patterns with steep REE patterns normalized by chondrite values and HREE enrichment. However, type 1 and type 2 Zrns have lower LREE concentrations as compared to that of type 3, which are quite enriched in LREE (Fig. 4b).

As previously mentioned, the Grt-Crd-Bt gneiss (43007B) might have been subjected a similar metamorphic temperature condition to that of the Grt-Bt gneiss (430T01B); however, their Grt compositional zoning patterns show slight differences. In the Grt-Crd-Bt gneiss, the major elements $(\mathrm{Mg}, \mathrm{Mn})$ in the Grt compositional 


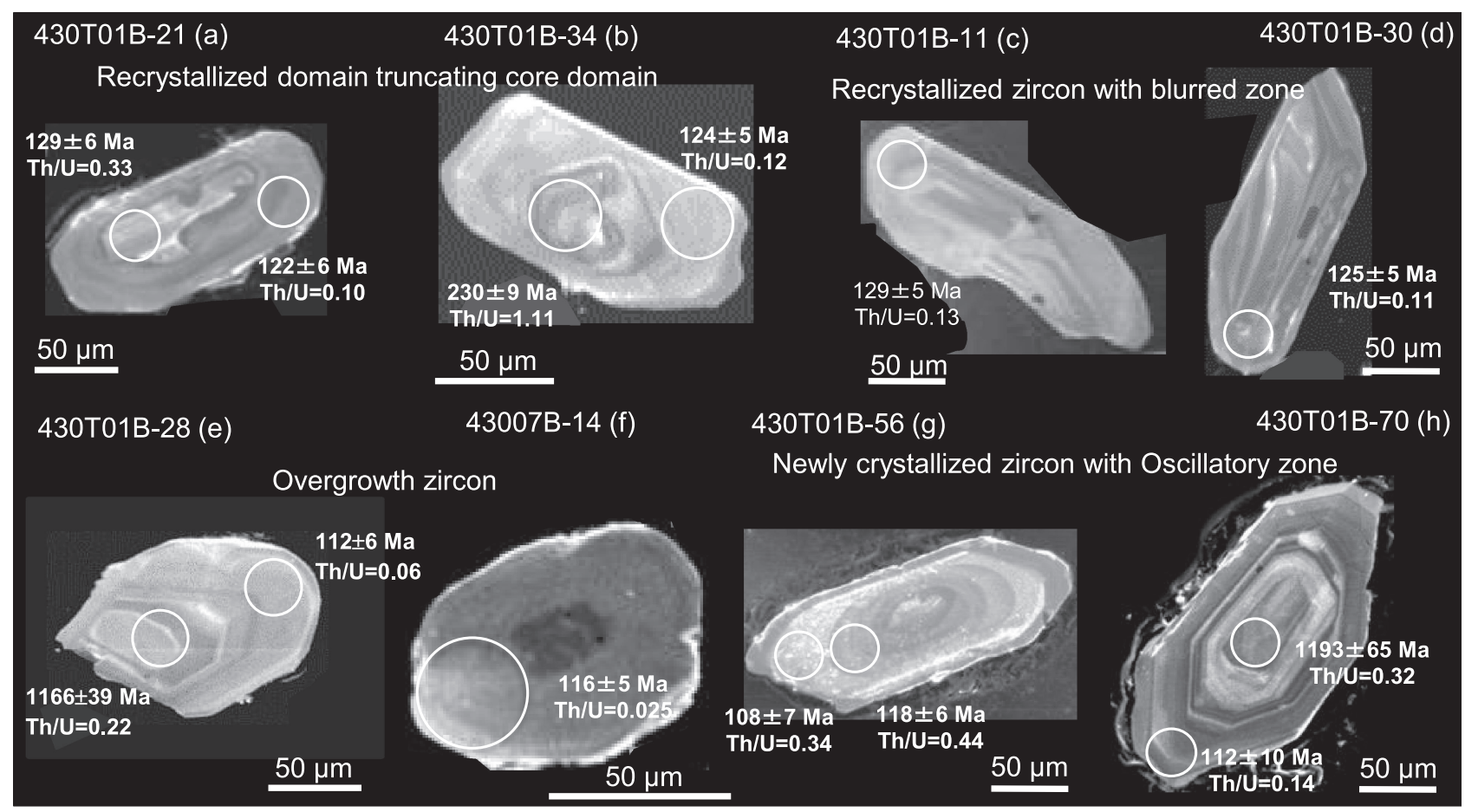

Figure 7. Representative internal zoning and texture of three metamorphic Zrn types in the Grt-Bt gneiss (a)-(e), (g), and (h). Grt-Crd-Bt gneiss (f). Recrystallized Zrn with an oscillatory core is truncated by an unzoned to faintly oscillatory rim (a) and (b). Recrystallized Zrn with blurred zone (c) and (d). Faintly oscillatory zoned to unzoned dark-CL core overgrown by a structureless rim (e) and (f). Newly crystallized euhedral Zrn showing oscillatory zoning texture (g) and (h).

zoning pattern show a wide homogeneous core and a reverse-zoned rim strongly suggesting the effect of diffusion during HT metamorphism and retrograde cooling. Y and $\mathrm{Ca}$ showed truncation as well as embayments along the lower right side of the Grt grain (Fig. 5a) that might have resulted from Grt resorption (Spear et al., 1995). The peak metamorphic condition was possibly preserved in the mantle (lower left side), corresponding to the highest $\mathrm{Mg}$ and lowest Mn. However, the Grt-Bt gneiss still preserved the prograde pattern in association with the diffusion pattern at the margin. The core to rim increase in $\mathrm{Ca}$ and $\mathrm{Mg}$ and decrease in $\mathrm{Mn}$ and $\mathrm{Fe}$ follows a similar pattern to that of the $\mathrm{Y}$ zoning (Fig. 5b). All of these elements show truncation along the lower right side of the Grt grain which is interpreted as Grt resorption (Spear et al., 1995) or pining of Grt grain boundaries adjacent to Qz (Pyle and Spear, 1999). The highest temperature condition was possibly recorded in the highest-Mg and lowest-Y rim of the Grt grain (Fig. 5b). Although the major element zoning pattern of the Grt is slightly different, the Grt in both samples show the same Y zoning pattern. The $\mathrm{Y}$ content decreases from the core to rim (Figs. 5a and $5 b$ ), typical prograde zoning for Grt (Pyle and Spear, 1999). Because the chemical behavior of the REE is similar to that of $\mathrm{Y}$, the same $\mathrm{Y}$ zoning pattern of the Grt in the Grt-Crd-Bt gneiss and Grt-Bt gneiss strongly suggests that the REE in both rock specimens preserve prograde chemical zoning.

To interpret the meaning of the two metamorphic ages of $\sim 110$ and $\sim 120 \mathrm{Ma}$, the HREE distribution coefficients between the metamorphic Zrn and Grt were calculated for both the Grt-Bt gneiss and Grt-Crd-Bt gneiss. Though this method has been shown by the empirical and experimental works of Rubatto and Hermann (2007) and Taylor et al. (2015) as well as applied in many studies (e.g., Whitehouse and Platt, 2003), there is some uncertainty regarding the data required for use and it should be used with caution. Partitioning coefficients calculated by Rubatto and Hermann (2007) for Zrn and Grt from HP granulite-facies metapelites $\left(800-1000{ }^{\circ} \mathrm{C}, 20 \mathrm{kbar}, \mathrm{Ca}-\right.$ rich Grt) showed greater than unity values and a steep pattern from ${ }^{\mathrm{Eu}-\mathrm{Lu}} \mathrm{D}_{\mathrm{Znn} / \mathrm{Grt}}$. This differs from the inferred partitioning of Whitehouse and Platt (2003) for granulitefacies metapelite $\left(750-800{ }^{\circ} \mathrm{C}, 4-8.5 \mathrm{kbar}\right.$; $\mathrm{Ca}$-poor $\left.\mathrm{Grt}\right)$ and Taylor et al. (2015) for UHT granulites $\left(900-1000{ }^{\circ} \mathrm{C}\right.$ at $7 \mathrm{kbar}$; $\mathrm{Ca}-\mathrm{free})$, which predict HREE partition coefficients that favor Grt over Zrn. However, all of them supposed that the HREE more favored in Grt with the temperature increasing. Their results also suggested that the chemistry of Grt, temperature, and pressure gave a great control on the partition coefficient, except the ${ }^{\text {Eu }} \mathrm{D}_{\mathrm{Zrn} / \mathrm{Grt}}$ which is approximately 1 in both data sets. 


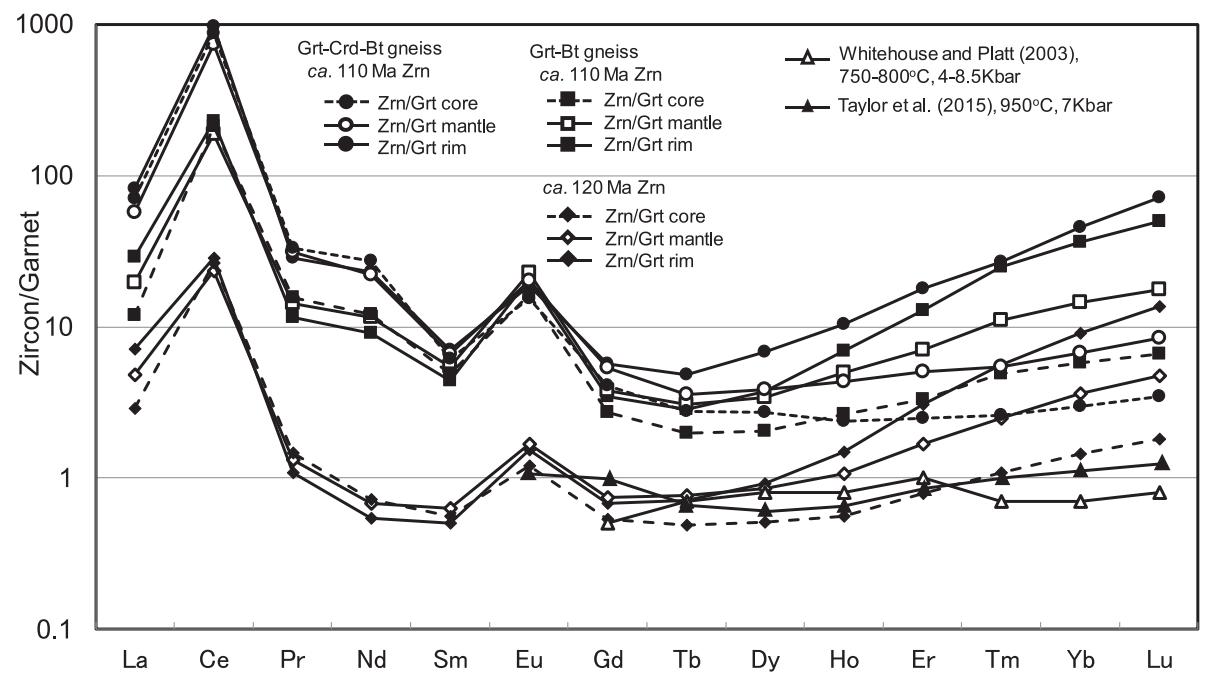

Figure 8. REE pattern of Zrn/Grt partitioning for metamorphic $\mathrm{Zrn}$ domain and Grt from the Grt-Crd-Bt gneiss and Grt-Bt gneiss.

Considering the low-Ca composition of the Grt in the current samples and published $P-T$ conditions in zone D (6 kbar and $820{ }^{\circ} \mathrm{C}$; Osanai et al., 1998), the partition coefficient values reported by Whitehouse and Platt (2003) and Taylor et al. (2015) are more suitable to apply to the current samples. For both samples, the ${ }^{\mathrm{HREE}} \mathrm{D}_{\mathrm{Zrn} / \mathrm{Grt}}$ values between the $\sim 110 \mathrm{Ma} Z \mathrm{Zrns}$ and Grt (core, mantle, and rim) in the Grt-Bt gneiss as well as the Grt (mantle and rim) in the Grt-Crd-Bt gneiss are significantly higher than 1 (Fig. 8), not typical equilibrium distribution values (Whitehouse and Platt, 2003; Taylor et al., 2015). Although the $\mathrm{D}_{\mathrm{Znn} / \mathrm{Grt}}$ shows nearly unity for Zrn-Grt $\mathrm{Core}_{\text {in }}$ the Grt-Crd-Bt gneiss, the $\mathrm{D}_{\mathrm{Znn} / \mathrm{Grt}}$ for $\mathrm{Eu}$ is significantly greater than unity (Fig. 8); therefore, the equilibrium state is also not approached. Nevertheless, the equilibrium state seems to be reached for the $\sim 120 \mathrm{Ma} \mathrm{Zrn}$ and Grt core (Grt-Bt gneiss) which has a nearly similar $\mathrm{D}_{\mathrm{Znn} / \mathrm{Grt}}$ value to those equilibrium ones reported by Whitehouse and Platt (2003) and Taylor et al. (2015), while the $\mathrm{D}_{\mathrm{Zrn} / \mathrm{Grt}}$ steepens for the Grt mantle-rim corresponding to the decreased HREE toward the Grt rim (Fig. 8). As previously mentioned, Grt has been proposed to grow during prograde metamorphism; therefore, the equilibrium between the $\sim 120 \mathrm{Ma} \mathrm{Zrn}$ and Grt core may indicate that the prograde metamorphic stage occurred at $\sim 120 \mathrm{Ma}$ when the Grt began to grow.

Moreover, the combination of internal textures, REE chemistry, and Zrn ages can also provide insight to infer the period of prograde, peak, and retrograde stages of the HT metamorphism. The $\sim 120$ Ma ages were obtained from the recrystallized $\mathrm{Zrn}$ rim only in the case of the Grt-Bt gneiss. Generally, this type of Zrn can form during the prograde stage because of the consumption of the protolith Zrn or during the later retrograde stage with the presence of fluid (Rubatto, 2017). The recrystallized
Zrn in this study showed the texture of blurred zones or truncated detrital cores without any resorption texture (Figs. 7a-7d) and the similarity in REE concentrations and patterns to those of the detrital cores (Fig. 4b). Thus, this may suggest that the $\sim 120$ Ma Zrns were recrystallized during the prograde stage, possibly occurring mainly at the expense of the precursor detrital Zrns. However, two types of Zrn provided a similar age result of $\sim 110$ Ma but differences in morphology, texture, and Th/U ratios. The ovoid Zrn with an unzoned overgrowth rim surrounding the oscillatory zoned or unzoned core, with low-Th/U ratios $(<0.10)$, was observed in both pelitic gneisses (Figs. 7e and 7f). These unzoned Zrns are considered to have formed via the $\mathrm{Zr}$-liberating reaction relating to the breakdown of Grt (e.g., Fraser et al., 1997; Whitehouse and Platt, 2003; Rubatto, 2017). Some ovoid Zrn occurrences in this study were observed near the Grt resorption part in both the Grt-Crd-Bt gneiss and Grt-Bt gneiss. Nevertheless, the newly crystallized Zrn has similar external and internal textures and $\mathrm{Th} / \mathrm{U}$ ratios to magmatic Zrn as previously mentioned. Most of the REE patterns represent slight LREE enrichment compared to the recrystallized and overgrowth Zrns with strong HREE enrichment (Fig. 4b). Therefore, this type of Zrn might be regarded as crystallized from the melt during cooling. The presence of melt in pelitic gneisses can be inferred by the occurrence of migmatitic texture (Fig. 2a) and subhedral Crd (Fig. 2d), euhedral Pl (Figs. 2c and 2f) and $\mathrm{Bt}$ (Figs. 2c-2e).

Interestingly, the metamorphic Zrn age of $\sim 120 \mathrm{Ma}$ was obtained from only the Crd-free sample (430T01B) but it was absent from the Crd-bearing sample (43007B). Under thin section, Zrn is mainly found as an inclusion in secondary Crd after Grt in the Grt-Crd-Bt gneiss (Fig. 2c) while it is often included in Grt and exists in the 

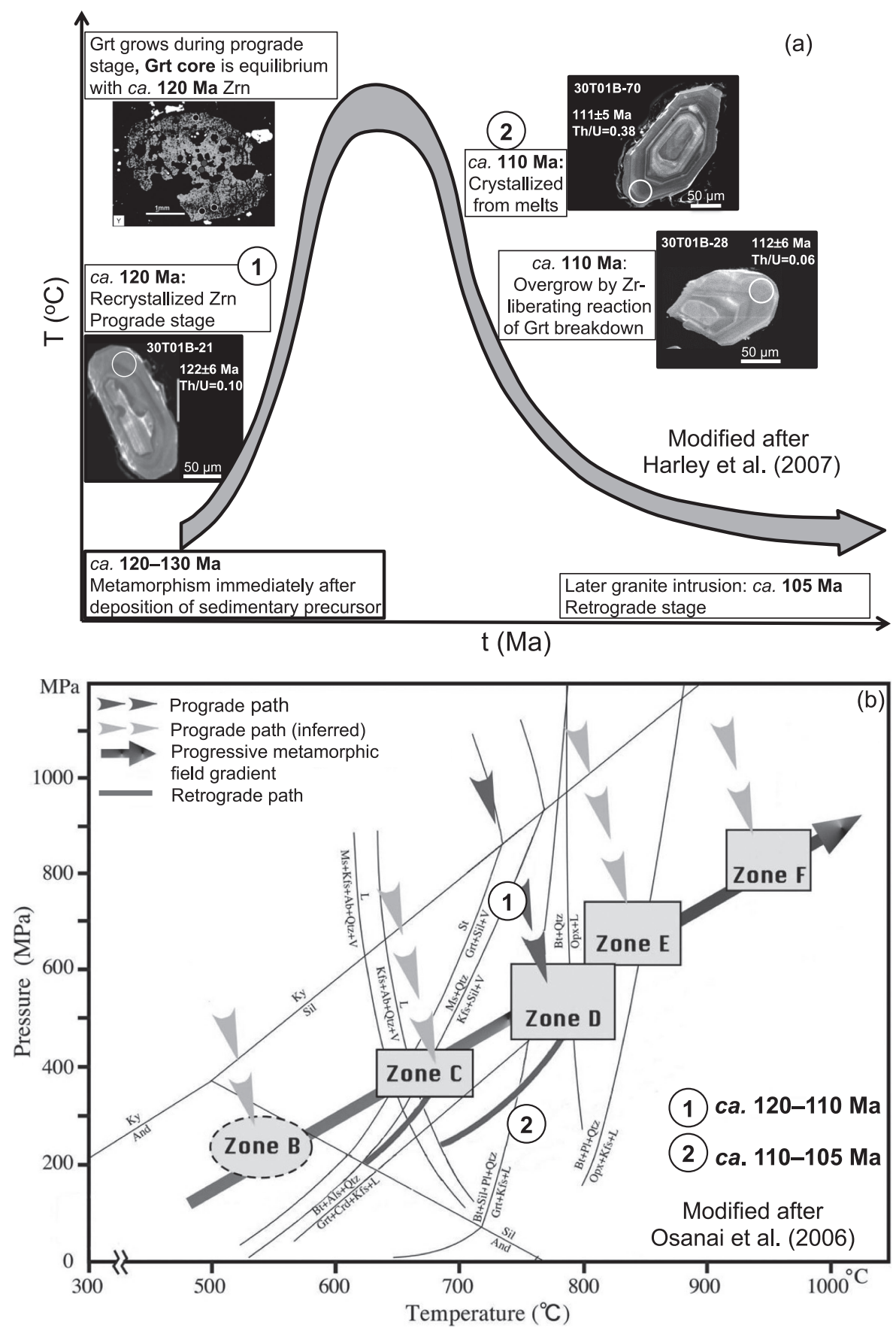

Figure 9. Summary diagram outlining the HT metamorphic history recorded by Zrn-Grt geochemistry and the $\mathrm{Zrn} \mathrm{U}-\mathrm{Pb}$ isotopic system in pelitic gneisses and a later granitic intrusion in the Higo metamorphic terrane (modified after Harley et al. 2007) (a). Corresponding to the $P-T$ path suggested by Osanai et al. (2006) (b). Color version is available online from https://doi. org/10.2465/jmps. 181115 .

matrix in the Grt-Bt gneiss (Fig. 2g). Generally, Zrn only crystallizes when $\mathrm{Zr}$ saturation is reached or $\mathrm{Zr}$ solubility decreases; it is assumed that the $\mathrm{Zr}$ saturation point is controlled by the temperature and bulk chemistry (Kohn et al., 2015; Rubatto, 2017). The absence of prograde Zrn in the Crd-bearing sample might be interpreted as a result of the different $\mathrm{Zr}$ saturation points between the two samples. Because both pelitic gneisses underwent a similar metamorphic condition, it might have been caused by the different bulk chemistry. Under the metamorphic condi- tion at $120 \mathrm{Ma}$, Zr saturation was reached in the Grt-Bt gneiss but not in the Grt-Crd-Bt gneiss.

In summary, these results suggest the following view of the HT metamorphism in the Higo metamorphic terrane (Fig. 9). The pelitic sedimentary protoliths were deposited until $\sim 130 \mathrm{Ma}$ as recorded by the youngest detrital $\mathrm{Zrn}$ age. The HT metamorphism occurred immediately after the deposition and the protolith Zrns recrystallized at $\sim 120$ Ma during the prograde stage. The pelitic gneisses might have undergone a peak metamorphic condition 
between $\sim 120$ and $\sim 110 \mathrm{Ma}$. The subsequent retrograde stage promoted new Zrn crystallization from melts and Grt breakdown at $\sim 110 \mathrm{Ma}$, finally involving granitic intrusion into pelitic gneisses at $\sim 105 \mathrm{Ma}$. Although the timing of the HT metamorphism in the Higo metamorphic terrane $(\sim 110-120 \mathrm{Ma})$ is consistent with that of previous studies (e.g., Sakashima et al., 2003; Takagi and Arai, 2003; Dunkley et al., 2008; Maki et al., 2014; Osanai et al., 2017; Suga et al., 2017), this study reconfirmed the rapid HT metamorphism framework from detailed observation of Zrn internal textures, REE chemistry, and $\mathrm{U}-\mathrm{Pb}$ ages, providing critical information to understand the tectonic evolution of this terrane.

\section{ACKNOWLEDGMENTS}

This study was funded from Ministry of Education, Culture, Sports, Science and Technology-Japan (MEXT) scholarship at Kyushu University. This study was also partly supported by JSPS KAKENHI Grant Numbers JP16H02743 and JP22244063 to Y. Osanai and Numbers JP15K05345 and JP18H01316 to N. Nakano. We are indebted to handling of the editor, associate editor and two anonymous reviewers for their critical comments regarding the manuscript, greatly improving it.

\section{SUPPLEMENTARY MATERIALS}

Color version of Figures 2, 5, and 9 and Supplementary Tables S1-S4 are available online from https://doi.org/ 10.2465/jmps.181115.

\section{REFERENCES}

Adachi, T., Osanai, Y., Nakano, N. and Owada, M. (2012) LAICP-MS U-Pb Zrn and FE-EPMA U-Th-Pb monazite dating of pelitic granulites from the Mt. Ukidake area, Sefuri Mountains, northern Kyushu. The Journal of Geological Society of Japan, 118, 29-52.

Dunkley, D., Suzuki, K., Hokada, T. and Kusiak, M. (2008) Constrasting ages between isotopic chronometers in granulites: Monazite dating and metamorphism in the Higo Complex, Japan. Gondwana Research, 14, 623-643.

Fraser, G., Ellis, D. and Eggins, S. (1997) Zirconium abundance in granulite-facies minerals, with implications for zircon geochronology in high-grade rocks. Geology, 25, 607-610.

Hamamoto, T., Osanai, Y. and Kagami, H. (1999) Sm-Nd, Rb-Sr and $\mathrm{K}-\mathrm{Ar}$ geochronology of Higo metamorphic terrane, westcentral Kyushu, Japan. The Island Arc, 8, 323-334.

Harley, S.L. (2002) Zircon-garnet REE distribution patterns and the behaviour of Zrn during UHT metamorphism. Programme with Abstracts, International Mineralogical Association 18, Edinburgh, 236.

Harley, S.L., Kelly, N.M. and Moller, A. (2007) Zircon behaviour and the thermal histories of mountain chains. Elements, 3, 2530 .
Hokada, T. and Harley, S.L. (2004) Zircon growth in UHT leucosome: constraints from Zrn-Grt rare earth elements (REE) relations in Napier Complex, East Antarctica. Journal of Mineralogical and Petrological Sciences, 99, 180-190.

Hoskin, P.W. and Black, L.P. (2000) Metamorphic zircon formation by solid-state recrystallization of protolith igneous zircon. Journal of Metamorphic Geology, 18, 423-439.

Hoskin, P.W.O. and Schaltegger, U. (2003) The composition of zircon and igneous and metamorphic petrogenesis, Zircon. Reviews in Mineralogy and Geochemistry, 53, 27-55.

Kohn, M.J., Corrier, S.L. and Markley, C. (2015) The fall and rise of metamorphic zircon. American Mineralogist, 100, 897908.

Maki, K., Ishizaka, Y. and Nishiyama, T. (2004) Staurolite-bearing gneiss and re-examination of metamorphic zonal mapping of the Higo metamorphic terrane in the Kosa area, central Kyushu, Japan. Journal of Mineralogical and Petrological Sciences, 99, 1-18.

Maki, K., Yui, T.K., Miyazaki, K., Fukuyama, M., Wang, K.L., Martens, U., Grove, M. and Liou, J.G. (2014) Petrogenesis of metatexite and diatexite migmatites determined using zircon $\mathrm{U}-\mathrm{Pb}$ age, trace element and $\mathrm{Hf}$ isotope data, Higo metamorphic terrane, central Kyushu, Japan. Journal of Metamorphic Geology, 32, 301-323.

McDonough, W.F. and Sun, S.S. (1995) Composition of the Earth. Chemical Geology, 120, 223-253.

Miyazaki, K. (2004) Low-P-high-T metamorphism and the role of heat transport by melt migration in the Higo Metamorphic Complex, Kyushu, Japan. Journal of Metamorphic Geology, 22, 793-809.

Nakano, N., Osanai, Y. and Adachi, T. (2010) Major and trace element zoning of euhedral garnet in high-grade $\left(>900{ }^{\circ} \mathrm{C}\right)$ mafic granulite from the Song Ma Suture zone, northern Vietnam. Journal of Mineralogical and Petrological Sciences, 105, 268-273.

Obata, M., Yoshimura, Y., Nagakawa, K., Odawara, S. and Osanai, Y. (1994) Crustal anataxis and melt migrations in the Higo metamorphic terrane, west-central Kyushu, Kumamoto, Japan. Lithos, 32, 135-147.

Osanai, Y., Hamamoto, T., Maishima, O. and Kagami, H. (1998) Sapphirine-bearing granulites and related high temperature metamorphic rocks from the Higo metamorphic terrane, west-central Kyushu, Japan. Journal of Metamorphic Geology, 16, 53-66.

Osanai, Y., Owada, M., Kamei, A., Hamamoto, T., Kagami, H., Toyoshima, T., Nakano, N. and Nam, T.N. (2006) The Higo metamorphic complex in Kyushu, Japan as the fragment of Permo-Triassic metamorphic complexes in East Asia. Gondwana Research 9, 152-166.

Osanai, Y., Nakano, N. and Adachi, T. (2017) Recent progress in lower crustal process: precise analyses on ultrahigh-temperature metamorphism. The Journal of the Geological Society of Japan, 123, 879-906.

Pyle, J.M. and Spear, S.F. (1999) Yttrium zoning in garnet: Coupling of major and accessory phases during metamorphic reactions. Geological Materials Research, 1, 1-49.

Rubatto, D. (2002) Zircon trace element geochemistry: partitioning with garnet and the link between $\mathrm{U}-\mathrm{Pb}$ ages and metamorphism. Chemical Geology, 184, 123-138.

Rubatto, D. (2017) Zircon: The metamorphic mineral. In Petrochronology: Methods and Applications (Kohn, M.J., Engi, M. and Lanari, P. Eds.). Reviews in Mineralogy and Geo- 
chemistry, 83, 261-295.

Rubatto, D. and Hermann, J. (2007) Experimental zircon/melt and zircon/garnet trace element partitioning and implications for the geochronology of crustal rocks. Chemical Geology, 241, 38-61.

Sakashima, T., Terada, K., Takeshita, T. and Sano, Y. (2003) Large-scale displacement along the Median Tectonic Line, Japan: Evidence from SHRIMP zircon U-Pb dating of granites and gneisses from the South Kitakami and paleo-Ryoke belts. Journal of Asian Earth Science, 21, 1019-1039.

Spear, F.S., Kohn, M.J. and Paetzold, S. (1995) Petrology of the regional Sil zone, west central New Hampshire, U.S.A., with implications for the development of inverted isograds. American Mineralogist, 80, 361-376.

Suga, K., Yu, T.F., Miyazaki, K., Sakata, S., Hirata, T. and Fukuyama, M. (2017) A revisit to the Higo terrane, Japan: The eastern extension of the North China-South China collision zone. Journal of Asian Earth Sciences 143, 218-235.

Takagi, H. and Arai, H. (2003) Restoration of Exotic Terranes Along the Median Tectonic Line, Japanese Islands: Overview.
Gondwana Research, 6, 657-668.

Taylor, R.J.M., Harley, S.L., Hinton, R.W., Elphick, S., Clark, C. and Kelly, N.M. (2015) Experimental determination of REE partition coefficients between zircon, garnet and melt: A key to understanding high-T crustal processes. Journal of Metamorphic Geology, 33, 231-248.

Whitehouse, M.J. and Platt, J.P. (2003) Dating high-grade metamorphism-constraints from rare earth elements in zircon and garnet. Contributions to Mineralogy and Petrology, 145, 6174.

Whitney, D.L. and Evans, B.W. (2010) Abbreviations for names of rock-forming minerals. American Mineralogist, 95, 185-187.

Wu, Y. and Zheng, Y. (2004) Genesis of zircon and its constraints on interpretation of $\mathrm{U}-\mathrm{Pb}$ age. Chinese Science Bulletin, 49, 1554-1569.

Manuscript received November 15, 2018

Manuscript accepted February 11, 2019

Published online April 23, 2019

Manuscript handled by Masaaki Owada 